\title{
Selective Removal of Semivolatile Components of Cigarette Smoke by Various Filters*
}

\author{
by Madelyn S. Baggett and Gerald P. Morie
}

Research Laboratories, Tennessee Eastman Company,

Division of Eastman Kodak Company, Kingsport, Tennessee, USA

\section{INTRODUCTION}

The term semivolatiles has been used to describe the volatile fraction of the particulate phase of smoke ( 1 ). This fraction includes acidic, basic, and neutral compounds important to the flavor and in some cases the physiological effects of smoke. Graham $(2,3)$ used two gas dromatographic columns to separate fractions of the semivolatiles, and Neurath, Dünger, and Küstermann (4) analyzed six fractions of this portion of smoke. Grob and Völlmin (5) and Baggett, Morie, Simmons, and Lewis (6) analyzed the semivolatile portion without prior fractionation. Grob and Völmin (5) did not present any quantitative or filtration data on the semivolatiles. Graham (3) reported the selectivity of $15 \mathrm{~mm}$ cellulose acetate filters and $15 \mathrm{~mm}$ paper filters for specific semivolatile components. In this paper the selectivity of cellulose acetate filters, with or without additives, and paper filters for the removal of several semivolatile components in cigarette smoke is discussed. The method employed could be used routinely for the determination of selectivity by experimental filters.

\section{EXPERIMENTAL}

All cigarettes were smoked under standard conditions (one $35 \mathrm{ml}, 2 \mathrm{~s} \mathrm{puff} / \mathrm{min}$ ) to a $28 \mathrm{~mm}$ butt length on a Filtrona 20-port smoking machine. The same brand of $64 \mathrm{~mm}$ domestic filter blend tobacco columns was used with $21 \mathrm{~mm}$ filters.

The whole smoke from 40 cigarettes was collected in $4 \mathrm{ml}$ of internal standard solution $(14.8 \mu \mathrm{g}$ normal undecane/ml of a 1:1 mixture of acetone-methylene

- Received for publication: 4th December, 1974. chloride) in a cold trap (7) immersed in liquid nitrogen. After the cigarettes were smoked, the flask was warmed to room temperature and the mixture was diluted to $5 \mathrm{ml}$ with additional internal standard solution. A $0.25 \mathrm{~mm}$ i.d., $160 \mathrm{~m}$ glass capillary column, wall coated with OV-101 liquid phase, was used for the gas dromatographic separation of the semivolatiles (Figure 1). The flow of nitrogen carrier gas was established at $1.85 \mathrm{ml} /$ min with a split ratio of $x: 1$. After a $0.1 \mu$ l sample was injected, the column temperature was maintained at $30^{\circ} \mathrm{C}$ for $12 \mathrm{~min}$ and then programmed to $200^{\circ} \mathrm{C}$ at $2 \% \mathrm{~min}$. A flame ionization detector was used for all analyses.

\section{Selective Removal}

Six sets of 40 cigarettes were made using commercial and experimental filters and the smoke was analyzed by gas chromatography. Control cigarettes were prepared by replacing the filters with $21 \mathrm{~mm}$ tobacco columns taken from similar cigarettes. The following filters were tested:

1. Cellulose acetate with $6 \%$ triacetin $\left[43 \%\right.$ TPM $^{*}$ removal].

2. Cellulose acetate with $6 \%$ triacetin and $6 \%$ glycerin [41\% TPM removal].

3. Cellulose acetate with $6 \%$ triacetin and $4 \%$ poly(ethylene-glycol) (PEG 600) [39\% TPM removal].

4. Cellulose acetate with $6 \%$ triacetin, $4 \%$ PEG 600 and $8 \%$ glycerin [ $43 \%$ TPM removal].

5. Paper [62\% TPM removal].

6. Cellulose acetate with $6 \%$ triacetin and containing $100 \mathrm{mg}$ activated carbon [39\% TPM removal].

* Total particulate matter.

Figure 1. Gas chromatographic separation of semivolatlle components of clgarette smoke.

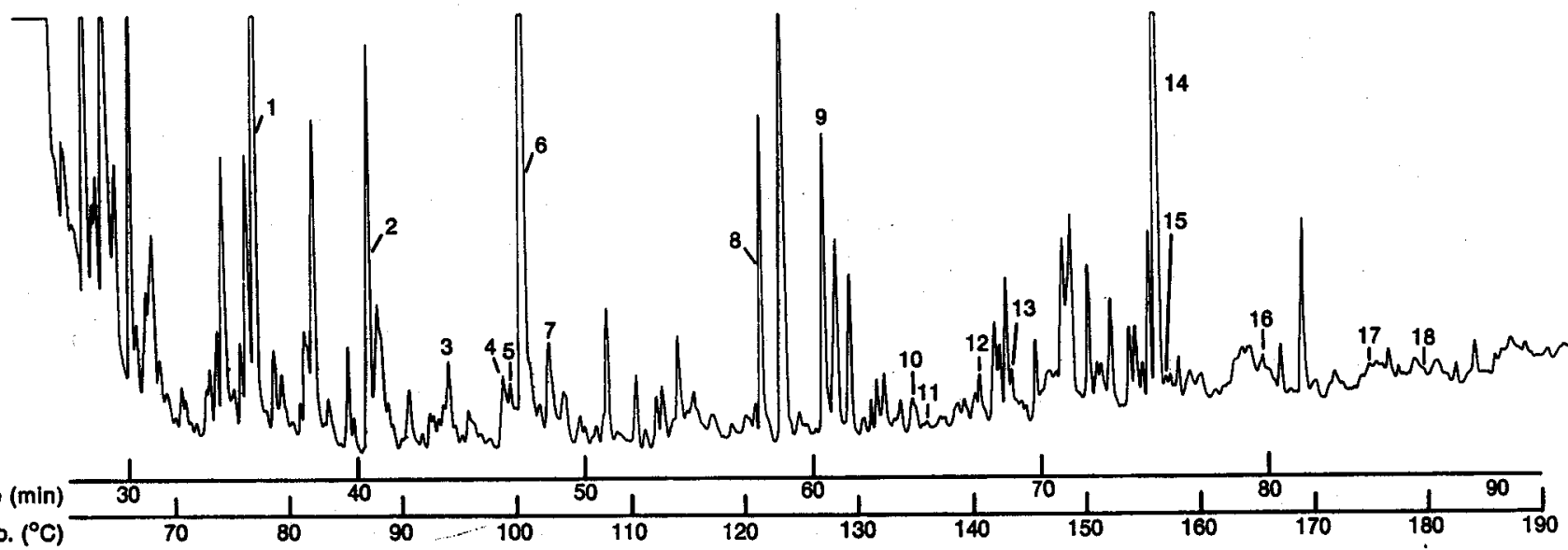


Table 1. Removal (R) and selectlvity (S) of various filters.

\begin{tabular}{|c|c|c|c|c|c|c|}
\hline & \multicolumn{2}{|c|}{$\begin{array}{c}\text { Cellulose } \\
\text { acetate } \\
+ \text { triacetin }\end{array}$} & \multicolumn{2}{|c|}{$\begin{array}{c}\text { Cellulose } \\
\text { acetate } \\
+ \text { trlacetin } \\
\text { and glycerin }\end{array}$} & \multicolumn{2}{|c|}{$\begin{array}{c}\text { Cellulose } \\
\text { acetate } \\
+ \text { trlacetin } \\
\text { and PEG } 600\end{array}$} \\
\hline & $R(\%)$ & $\mathbf{S}$ & $R(\%)$ & $\mathbf{s}$ & $R(\%)$ & $\mathbf{s}$ \\
\hline Benzene & 20 & 0.71 & 22. & 0.76 & 13 & 0.70 \\
\hline 2,5-Dimethylfuran & 29 & 0.80 & 42 & 1.02 & 31 & 0.88 \\
\hline Vinylcyclopentene & 26 & 0.61 & 36 & 0.92 & 30 & 0.87 \\
\hline 3-Heptyne & 40 & 0.95 & 36 & 0.92 & 29 & 0.86 \\
\hline Ethylcyclopentene & 38 & 0.92 & 33 & 0.88 & 25 & 0.81 \\
\hline Toluene & 31 & 0.83 & 33 & 0.88 & 15 & 0.72 \\
\hline Paraldehyde & 73 & 2.11 & 59 & 1.44 & 61 & 1.56 \\
\hline $\mathrm{m}$ - and $\mathrm{p}$-Xylenes & & & 20 & 0.74 & & \\
\hline Styrene + o-xylene & & & 28 & 0.82 & 15 & 0.72 \\
\hline Cumene & 52 & 1.19 & 73 & 2.19 & 70 & 2.03 \\
\hline $\begin{array}{l}\text { 5-Methyl-2- } \\
\text { furaldehyde }\end{array}$ & 71. & 1.97 & 50 & 1.18 & 57 & 1.42 \\
\hline Benzaldehyde & 13 & 0.66 & 7 & 0.63 & 3 & 0.63 \\
\hline Benzonitrile & 39 & 0.93 & 54 & 1.28 & 36 & 0.95 \\
\hline Limonene & 14 & 0.66 & 21 & 0.75 & 23 & 0.79 \\
\hline Indene & 65 & 1.63 & 83 & 3.47 & 87 & 4.69 \\
\hline p-Cresol & 61 & 1.46 & 67 & 1.79 & 72 & 2.18 \\
\hline Methylindene & 50 & 1.14 & 63 & 1.59 & 57 & 1.42 \\
\hline Naphthalene & 50 & 1.14 & 50 & 1.18 & 59 & 1.49 \\
\hline
\end{tabular}

The peak height ratio of each of the 20 semivolatile compounds to undecane, the internal standard, was determined. The average ratio for each compound was calculated for each filter. Then this value was compared to the average ratio for that compound in the cigarette with the tobacco filter. Thus, the percentage removals by a given filter were determined for the 20 compounds. The selectivity of a filter for a specific compound was determined by using the formula of Davis and George (8):

$$
S_{x}=\left(1-R_{T P M}\right) /\left(1-R_{x}\right),
$$

where $R_{T P M}$ and $R_{x}$ are the fractional retentions of TPM and component $x$, respectively. The percentage removal and selectivity of these six filters for the 20 compounds are given in Tables 1 and 2.

\section{RESULTS AND DISCUSSION}

A rapid method to obtain an overall chromatographic picture of the semivolatile fraction of smoke was developed so that the selectivity of filters, with and

Table 3. Identification of semivolatile components In Figure 1.
1. Benzene
10. Cumene
2. 2,5-Dimethylfuran
3. Vinylcyclopentene
4. 3-Heptyne
5. Ethylcyclopentene
6. Toluene
7. Paraldehyde
8. $m$ - and $p$-Xylenes
9. Styrene $+0-x y l e n \theta$

Table 2. Removal (R) and selectlvity (S) of varlous filters.

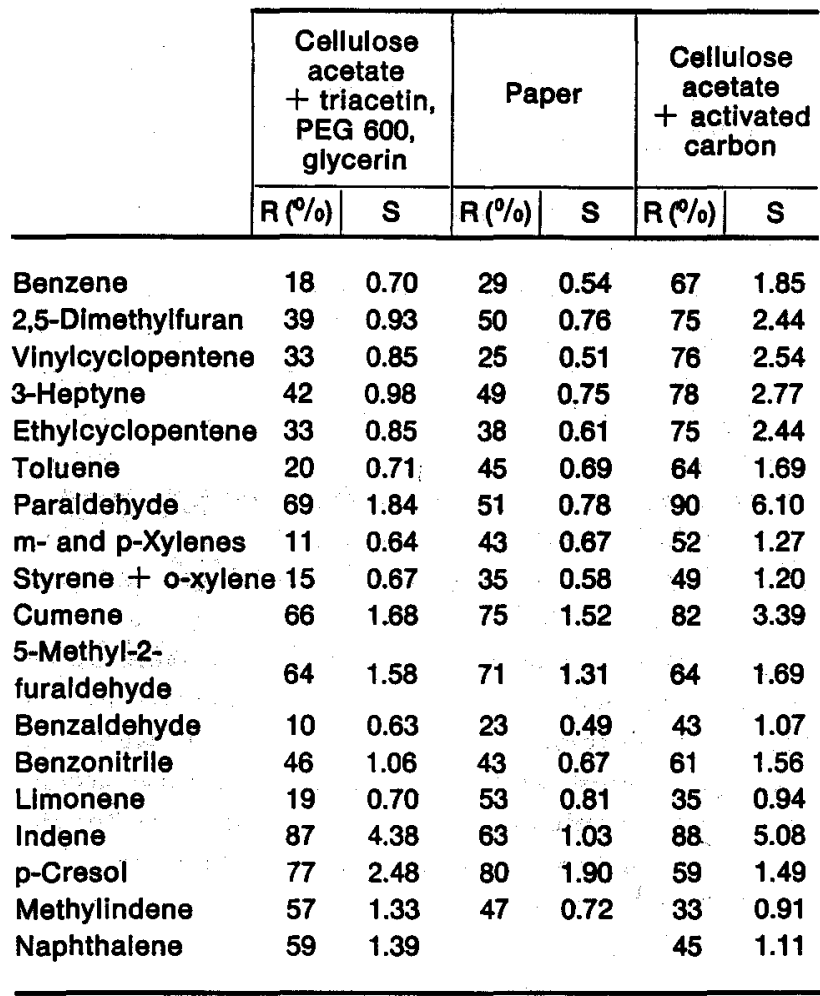

without additives, could be determined. A highly precise method was sacrificed for one that could be performed routinely. The analysis of the semivolatiles requires approximately 2 hours, and includes compounds with boiling points of $80^{\circ}$ (benzene) to $246^{\circ} \mathrm{C}$ (nicotine). The removal and selectivity for each filter were determined for those smoke compounds that are representative of different classes of compounds containing various functional groups. Predictions based on the removal of these compounds by filters were made for the removal of similar compounds known to be present in cigarette smoke.

The addition of glycerin to a standard cellulose acetate filter with triacetin increased the removal of 2,5dimethylfuran, cumene, benzonitrile, limonene, and indene. Glycerin decreased the removal of paraldehyde, 5-methyl-2-furaldehyde, benzaldehyde, and naphthalene. From these data, one could expect the removal of other terpenes to be increased and the removal of other higher boiling aldehydes to be decreased by the addition of glycerin to a standard acetate filter. Since the addition of PEG 600 to an acetate filter increased the removal of cumene, limonene, indene, and p-cresol, it should also increase the removal of other terpenes and phenols. The removal of hydrocarbons and aldehydes was decreased by the addition of PEG 600. A cellulose acetate filter with activated carbon is known to be more selective for the vapor phase of smoke than is a cellulose acetate filter with triacetin. Therefore, it was not surprising that all of the compounds tested through cumene (boiling point $152^{\circ} \mathrm{C}$ ) were removed to a greater extent by the activated carbon filter. 
The semivolatile portion of cigarette smoke contains acidic, basic, and neutral compounds that are important to the flavor and in some cases the physiological effects of smoke. A rapid method that could be used routinely for the gas chromatographic analysis of this portion of smoke was developed. A $160 \mathrm{~m}$ glass capillary column was used to resolve approximately 150 semivolatile smoke components. Gas chromatography - mass spectrometry was used to identify about 35 of these components. Twenty known semivolatile compounds with different functional groups and boiling points were used to determine the effects of various filters on their removal from smoke. Standard cellulose acetate filters, cellulose acetate filters with glycerin, cellulose acetate filters with PEG 60o, and cellulose acetate filters with activated carbon were evaluated. The cellulose acetate filters with glycerin and PEG 600 were more selective for the removal of aromatic hydrocarbons than were the standard cellulose acetate filters. The cellulose acetate filters with activated carbon were more selective for the removal of the low-boiling semivolatile compounds than were the other filters tested.

\section{ZUSAMMENFASSUNG}

Der halbfüchtige Anteil des Cigarettenrauches enthält saure, basische und neutrale Verbindungen, die für den Geschmack und in einigen Fällen für die physiologische Wirkung des Rauches wichtig sind. Es wurde eine Schnellmethode entwickelt, die für die gaschromatographische Routineuntersuchung dieses Teiles des Rauches verwendet werden kann. Zur Trennung von etwa 150 halbflüdtigen Rauhinhaltsstoffen wurde eine Glaskapillarsäule von $160 \mathrm{~m}$ Länge benutzt. Gaschromatographie gekoppelt mit Massenspektrometrie diente zur Identifizierung von etwa 35 dieser Verbindungen. Anhand von zwanzig bekannten halbflüdtigen Verbindungen mit unterschiedlichen funktionellen Gruppen und Siedepunkten wurde untersucht, in welchem Maße verschiedene Filter diese Substanzen aus dem Rauch entfernen. Es wurde die Wirkung von normalen Celluloseacetatfiltern und von Celluloseacetatfiltern, denen jeweils Glycerin, PEG 600 und Aktivkohle zugesetzt worden war, untersucht. Die Celluloseacetatfilter mit Glycerin bzw. PEG 600 zeigten bei aromatischen Kohlenwasserstoffen eine größere selektive Wirkung als die normalen Celluloseacetatfilter. Die Celluloseacetatfilter mit Aktivkohle erwiesen sich bei der Entfernung der halbflüchtigen Verbindungen mit niedrigem Siedepunkt als stärker wirksam als die anderen untersuchten Filter.
La partie semivolatile de la fumée de cigarette contient des composés acides, basiques et neutres qui sont, chacun, importants pour le gout et, parfois, les effets physiologiques de la fumée. Une méthode pour l'analyse en série de cette partie de la fumée par la dhromatographie en phase gazeuse a été développée. Une colonne capillaire d'une longueur de $\mathrm{x} 60$ mètres est utilisée pour la résolution de 150 composés semivolatils de la fumée. Par la dhromatographie-spectrométrie de masse, environ 35 de ces composés ont été identifiés. On a utilisé 20 composés semivolatils connus, ayant des groupes fonctionnels et tempétatures d'ébullition différents, pour déterminer les effets de plusieurs sortes de filtres sur leur élimination de la fumée. On a essayé: des filtres d'acétate de cellulose ordinaire, des filtres d'acétate de cellulose contenant de la glycérine, des filtres d'acétate de cellulose contenant des poly(éthylène-glycols) et des filtres d'acétate de cellulose avec du charbon actif. Les filtres d'acétate de cellulose contenant de la glycérine ou des poly(éthylèneglycols) sont plus sélectifs pour l'élimination des hydrocarbures aromatiques que les filtres d'acétate de cellulose ordinaire. Les filtres d'acétate de cellulose avec du charbon actif sont plus sélectifs pour l'élimination des composés semivolatils à point d'ébullition bas que les autres filtres essayés.

\section{REFERENCES}

1. Williamson, J. T., J. F. Graham, and D. R. Allman: Beitr. Tabakforsch. 3 (I965) 233.

2. Graham, J. F.: Beitr. Tabakforsch. 5 (1969) 43.

3. Graham, J. F.: Beitr. Tabakforsch. 5 (1970) 220.

4. Neurath, G., M. Dünger, and D. Küstermann: Beitr. Tabakforsch. 6 (1971) 12.

5. Grob, K., and J. A. Völlmin: Beitr. Tabakforsch. 5 (1969) 52.

6. Baggett, M. S., G. P. Morie, M. W. Simmons, and J. S. Lewis: J. Chrom. 97 (1975) 79.

7. Elmenhorst, H.: Beitr. Tabakforsch. 3 (1965) $x$ ox.

8. Davis, T. W., and W. T. George: Beitr. Tabakforsch. 3 (1965) 205.

The authors' address:

Research Laboratories, Tennessee Eastman Company, Division of Eastman Kodak Company, Kingsport,

Tennessee, 37662, USA. 